УДК $324+328$

\title{
An assessment of the election system in Turkey
}

\section{Tanju Tosun, Gülgün Erdoğan Tosun, Yusufcan Gökmen}

Ege University, Faculty of Economics and Administrative Sciences, Bornova - Izmir, 35040, Turkey

For citation: Tosun T., Tosun G.E., Gökmen Yu. An assessment of the election system in Turkey. Digest of World Politics, vol. 10, ed. by T. S. Nemchinova, St. Petersburg, St. Petersburg State University Press, 2020, pp.277-300. https://doi.org/10.21638/11701/26868318.20

Introduction. Electoral systems are institutional arrangements that offer information on the level of the democracy standards of a country. Whether an electoral system is majoritarian, proportional representation or mixed is related to the historical conditions of the country, the preferences of the political elite and to the socio-economic structure. Although the parliamentary structure was formed with proportional representation methods in almost all elections held in Turkey after 1961, the electoral threshold proportional representation system applied partially during 1960-80 and fully since 1983 allowed especially strong parties to be represented in the parliament much higher than their vote rates and as a result a representation injustice problem prevailed in the context of the relation between the voters and the elected.

The government system changed with the April 16, 2017 Constitution referendum has put a new situation before the political system of Turkey. Although this situation disables the legislature, it can be said the significance of the election method of this institution was maintained and even increased. The situation that emerged from the November 1 elections indicated that the dominant party system with Ak Parti continued to exist. However, it is understood that the 4-party structure ideologically representing social-democracy, Turkish Nationalism and Kurdish nationalism shall not be easily dissolved. The only condition for the dissolution of this structure is for the IYII Parti, founded by Meral Akşener who stated that she would position herself in the center, to severely break the voter base of MHP, in which case a 5-party structure may exist for a certain period. However, the interesting point is that if MHP and the party to be found by Akşener fail to pass the electoral threshold and HDP, representing the Kurds also fail to pass the threshold then a 2-party structure may also be formed in the parliament after the next elections. 
Therefore, as stability in government has lost its meaning in the new regime, it can be possible to establish pluralism and democracy in the politics of Turkey to the extent that the electoral system reflects justice in representation. Due to the transition to the presidential regime, regarding the electoral systems design the topic to be discussed in the forthcoming days should not be the dichotomy of "Justice in representation, Stability in government» but it is essential to build the system on the foundations of «justice, pluralism and representation». In this study, first the phenomenon of justice in elections will be discussed based on the example of the electoral system, then the nature of the electoral systems implemented in Turkey since 1983 causing injustice in representation will be set forth and a system emphasizing «justice, pluralism and representation» shall be proposed.

Criteria in the Preference of Electoral Systems and Consequences Therefor. Various criteria are utilized in the preference of electoral systems depending on the aims of the decision-makers. Factors such as the socio-economic structures, political conditions, the nature of the political regime and the expectations of political powers determine this preference. These are also accepted as the objectives of electoral systems and political-scientist Horowitz discussed 6 objectives in this regard: proportionality between vote distribution and chair distribution, accountability, formation of stable governments, election of the candidate most desired by the people, allowing for compromise between various ethnic and religious groups and the representation of minorities [1, p. 161; 2, pp. 115-127]. In the last analysis the preferred criteria result in more or less political consequences and the most important of these consequences is related to justice in representation, the number of parties represented in the parliament and the degree of disproportionality of the system [3, pp.521-539]. In this study, justice in representation, one of the most significant aspects of the electoral system, shall be discussed first. In evaluating the extent to which an electoral system is just in terms of representation, as the basic indicator one has to consider the proportionality reflecting the relation between the votes received and the chairs won by parties participating in the elections.

Justice in representation is related to reflecting voter preferences to the parliament and there is injustice in representation if the votes in the elections and the chair distribution are different. The basic factors causing this are unrepresented votes and disproportionality. If votes supporting a party or political opinion are left out of the parliament due to various attributes of the electoral system, then there are unrepresented votes there. After a certain point the increase of such votes turns into a representa- 
tion problem [1, pp.161-162]. The problem of unrepresented votes is more evident in the majority system as party receiving the majority of the votes takes all the chairs. However, this does not mean that there is no injustice in representation in proportional representation systems. In particular, whether or not an electoral threshold is in place or the size of the threshold, whether the electoral threshold is national or regional, the size of the constituency and the chair formula can lead to injustice in the proportional representation system. However, it must be noted that the real determinant is disproportionality. Hence, the Netherlands, where the electoral threshold is around 1 percent has the lowest disproportionality ratio while disproportionality is a serious problem in Poland where the threshold is 5 percent. In particular, electoral threshold together with the size of the constituency jointly lead to further injustice in representation. Disproportionality increases as the constituency gets smaller and the situation that emerges with the existence of both, expressed by Taagepera as «effective threshold» is when injustice in representation becomes evident [1, pp. 163-164; 4, p. 12; 5, pp. 393-404].

In terms of proportionality between vote distribution and chair distribution, the adopted electoral system leads to proportionality or disproportionality between the votes of parties formed with voter preference and the ratio of deputies of parties, shaped by the electoral system. The higher the disproportionality the less that votes received by parties are represented in the parliament. This implies a deviation between the vote rates and deputy rates of parties and political scientists such as Douglas W. Rae, John Loosemoore and Victor J. Hanby, Michael Gallaver, Bernard Grofman and Arend Lijphart developed various formulas for measuring the degree of disproportionality [2, p.526].

Disproportionality in the Electoral Systems of Various Countries. The average disproportionality degrees identified by Arend Lijphart in the legislature elections in 36 democracies during the period 1945-1996 indicates that disproportionality differs significantly depending on the adopted electoral system. The following table provides findings on this issue.

As seen in the aforementioned table, among the examined countries the Netherlands, where proportional representation is implemented, is the country with the lowest disproportionality ratio of $1,30 \%$ whereas France is the country with the highest rate of $21,08 \%$. Another clearly striking issue in the table is that disproportionality is lower in countries with proportional representation and higher in countries with a majoritarian system. 
Table 1. Average Degrees of Disproportionality in Legislature Elections in 36 Democracies During the Period 1945-96*

\begin{tabular}{|c|c|c|c|c|c|}
\hline Country & $\begin{array}{c}\text { Degree of } \\
\text { Dispropor- } \\
\text { tionality }\end{array}$ & $\begin{array}{c}\text { Electoral } \\
\text { System }\end{array}$ & Country & $\begin{array}{c}\text { Degree of } \\
\text { Dispropor- } \\
\text { tionality }\end{array}$ & $\begin{array}{c}\text { Electoral } \\
\text { System }\end{array}$ \\
\hline $\begin{array}{l}\text { The } \\
\text { Netherlands }\end{array}$ & 1,30 & $\begin{array}{l}\text { Proportional } \\
\text { representa- } \\
\text { tion }\end{array}$ & Spain & 8,15 & $\begin{array}{l}\text { Proportional } \\
\text { representation }\end{array}$ \\
\hline Denmark & 1,83 & $\begin{array}{l}\text { Proportional } \\
\text { representa- } \\
\text { tion }\end{array}$ & Australia & 9,26 & $\begin{array}{l}\text { Absolute Ma- } \\
\text { joritarian }\end{array}$ \\
\hline Sweden & 2,09 & $\begin{array}{l}\text { Proportional } \\
\text { representa- } \\
\text { tion }\end{array}$ & $\begin{array}{l}\text { Papua New } \\
\text { Guinea }\end{array}$ & 10,06 & $\begin{array}{l}\text { Proportional } \\
\text { Majoritarian }\end{array}$ \\
\hline Israel & 2,27 & $\begin{array}{l}\text { Proportional } \\
\text { representa- } \\
\text { tion }\end{array}$ & $\begin{array}{l}\text { United } \\
\text { Kingdom }\end{array}$ & 10,33 & $\begin{array}{l}\text { Proportional } \\
\text { Representa- } \\
\text { tion }\end{array}$ \\
\hline Malta & 2,36 & $\begin{array}{l}\text { Proportional } \\
\text { Representa- } \\
\text { tion - Re- } \\
\text { sidual vote }\end{array}$ & Colombia & 10,62 & $\begin{array}{l}\text { Proportional } \\
\text { representa- } \\
\text { tion* }\end{array}$ \\
\hline Austria & 2,47 & $\begin{array}{l}\text { Proportional } \\
\text { representa- } \\
\text { tion }\end{array}$ & $\begin{array}{l}\text { New } \\
\text { Zealand }\end{array}$ & 11,11 & $\begin{array}{l}\text { Proportional } \\
\text { Majoritarian }\end{array}$ \\
\hline Germany & 2,52 & $\begin{array}{l}\text { Proportional } \\
\text { representa- } \\
\text { tion }\end{array}$ & India & 11,38 & $\begin{array}{l}\text { Proportional } \\
\text { Majoritarian }\end{array}$ \\
\hline Switzerland & 2,53 & $\begin{array}{l}\text { Proportional } \\
\text { representa- } \\
\text { tion }\end{array}$ & Canada & 11,72 & $\begin{array}{l}\text { Proportional } \\
\text { Majoritarian }\end{array}$ \\
\hline Finland & 2,93 & $\begin{array}{l}\text { Proportional } \\
\text { representa- } \\
\text { tion }\end{array}$ & Botswana & 11,74 & $\begin{array}{l}\text { Proportional } \\
\text { Majoritarian }\end{array}$ \\
\hline Belgium & 3,24 & $\begin{array}{l}\text { Proportional } \\
\text { representa- } \\
\text { tion }\end{array}$ & Costa Rica & 13,65 & $\begin{array}{l}\text { Proportional } \\
\text { representa- } \\
\text { tion }^{\star}\end{array}$ \\
\hline
\end{tabular}


An assessment of the election system in Turkey

\begin{tabular}{|c|c|c|c|c|c|}
\hline Country & $\begin{array}{c}\text { Degree of } \\
\text { Dispropor- } \\
\text { tionality }\end{array}$ & $\begin{array}{l}\text { Electoral } \\
\text { System }\end{array}$ & Country & $\begin{array}{c}\text { Degree of } \\
\text { Dispropor- } \\
\text { tionality }\end{array}$ & $\begin{array}{l}\text { Electoral } \\
\text { System }\end{array}$ \\
\hline Italy & 3,25 & $\begin{array}{l}\text { Proportional } \\
\text { representa- } \\
\text { tion }\end{array}$ & Trinidad & 13,66 & $\begin{array}{l}\text { Proportional } \\
\text { Majoritarian }\end{array}$ \\
\hline Luxembourg & 3,26 & $\begin{array}{l}\text { Proportional } \\
\text { representa- } \\
\text { tion }\end{array}$ & Venezuela & 14,41 & $\begin{array}{l}\text { Proportional } \\
\text { representation }\end{array}$ \\
\hline Ireland & 3,45 & $\begin{array}{l}\text { Proportional } \\
\text { Representa- } \\
\text { tion - Re- } \\
\text { sidual vote }\end{array}$ & USA & 14,91 & $\begin{array}{l}\text { Proportional } \\
\text { Majoritarian }\end{array}$ \\
\hline Portugal & 4,04 & $\begin{array}{l}\text { Proportional } \\
\text { representa- } \\
\text { tion }\end{array}$ & Bahama & 15,47 & $\begin{array}{l}\text { Proportional } \\
\text { Majoritarian }\end{array}$ \\
\hline Iceland & 4,25 & $\begin{array}{l}\text { Proportional } \\
\text { representa- } \\
\text { tion }\end{array}$ & Barbados & 15,75 & $\begin{array}{l}\text { Proportional } \\
\text { Majoritarian }\end{array}$ \\
\hline Norway & 4,93 & $\begin{array}{l}\text { Proportional } \\
\text { representa- } \\
\text { tion }\end{array}$ & Mauritius & 16,43 & $\begin{array}{l}\text { Proportional } \\
\text { Majoritarian }\end{array}$ \\
\hline Japan & 5,03 & $\begin{array}{l}\text { Non-Trans- } \\
\text { ferrable - } \\
\text { Residual } \\
\text { Vote }\end{array}$ & Jamaica & 17,75 & $\begin{array}{l}\text { Proportional } \\
\text { Majoritarian }\end{array}$ \\
\hline Greece & 8,08 & $\begin{array}{l}\text { Proportional } \\
\text { representa- } \\
\text { tion }\end{array}$ & France & 21,08 & $\begin{array}{l}\text { Absolute Ma- } \\
\text { joritarian* }\end{array}$ \\
\hline
\end{tabular}

* Arend Lijphart. Patterns of Democracy: Government Forms and Performance in Thirty-Six Countries, New Haven, Conn., Yale University Press, 1999; Demokrasi Motifleri (trans. Güneş Ayas, Utku Umut Bulsun), Salyangoz Yayınları, Istanbul, 2006. P. 161.

Injustice in the Electoral Systems and Disproportionality in the Parliamentary Elections in Turkey. We can examine the reflections of the electoral systems implemented in Turkey on the party system with the 
help of the various indicators provided in the following table. Among these indicators, the total vote and chair ratios of the two strongest parties and the disproportionality ratios thereof are provided in the following table 2 .

Table 2. Injustice in Representation and Disproportionality in Legislature Elections Since 1983*

\begin{tabular}{|c|c|c|c|c|c|c|c|c|c|}
\hline Electoral System & 1983 & 1987 & 1991 & 1995 & 1999 & 2002 & 2007 & 2011 & 2015 \\
\hline & 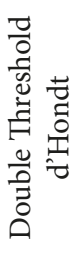 & 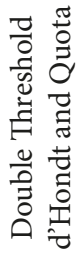 & 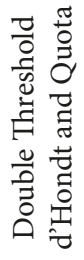 & 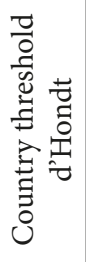 & 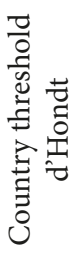 & 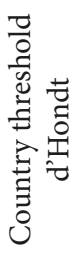 & 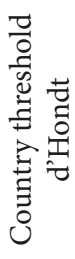 & 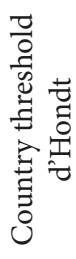 & 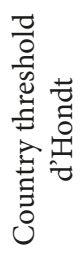 \\
\hline $\begin{array}{l}\text { Vote of Two } \\
\text { Strongest Parties } \\
(\%)\end{array}$ & 75,6 & 61,1 & 51 & 41 & 40,2 & 53,7 & 67,5 & 75,8 & $\begin{array}{c}65,7 \\
(74,8)\end{array}$ \\
\hline $\begin{array}{l}\text { Chairs of Two } \\
\text { Strongest Parties } \\
(\%)\end{array}$ & 81,9 & 86,9 & 65,2 & 53.2 & 48,1 & 98,3 & 82,3 & 84 & $\begin{array}{c}70,9 \\
(81,9)\end{array}$ \\
\hline $\begin{array}{l}\text { Disproportionality } \\
(\%)\end{array}$ & 4,5 & 15,7 & 7,1 & 5,8 & 4,1 & 22,4 & 8,0 & 5,0 & $\begin{array}{c}5,2 \\
(3,4)\end{array}$ \\
\hline
\end{tabular}

* The degrees of disproportionality in Tables 3 and 4 were obtained from the following work for pre-2007: Ergun Özbudun; Türkiyede Parti ve Seçim Sistemi, İstanbul Bilgi Üniversitesi Yayınları, no: 366, Istanbul, 2011. P.101. I calculated the post-2007 values using data from the Supreme Election Council and TurkStat. The first of the 2015 data belongs to the June 7 elections and the second to the November 1, 2015 elections.

Examining the findings regarding the November 6, 1983 elections, we can observe that due to its nature of not allowing the representation of a large section of the electorate, the double threshold gave results close to that of the majoritarian system. Despite the total vote ratio of 75,6\% received by ANAP and the People's Party, the two strongest parties of the election, the fact that they represented $81,9 \%$ of the chair in the parliament had damaged the principle of justice in representation. 
The effects of the system, which is to the advantage of large parties and excludes the preferences of a significant portion of electorate from the democratic convention, were also felt in the 1987 elections. Even considering only the disproportionality ratio $(15,7 \%)$, the fact that disproportionality reach its peak in 1987 among all the elections held between 1961 and 2002, reveals the extent of injustice in representation. The same injustice can also be observed by examining the fact that despite a total vote ratio of $61,1 \%$, ANAP and SHP, the two strongest parties obtained a chair ratio of $86,9 \%$.

Although the limited changes made especially in the constituency threshold before the 1991 elections were to the benefit of smaller parties, the fact that the parties other than the three strongest parties and independent candidates could not pass the country threshold with the 4749232 votes (approximately one fifth of total votes) they received in the 1987 elections, led parties to seek alliances. Examining the impact that the system implemented in 1991 had on the party system, the fact that the two largest parties gained $65,2 \%$ of the chairs in the parliament despite having received $51 \%$ of the votes clearly indicates that the system was to the advantage of large parties. The fact that disproportionality was 7,1\% reflected that proportional representation was approaching majority rule as the case was in 1983 and 1987.

Although the constituency threshold was annulled in the 1995 elections, the 10 percent country threshold continued to lead to disproportionality and injustice in representation. This meant that the justice in representation aimed by proportional representation was eliminated through thresholds. The fact that MHP and HADEP failed to have deputies in the parliament despite a vote of 3472966 proved this. Although the disproportionality ratio of 5,8\% was lower compared to 1987 and 1991, it was twice compared to 1983. Although based on proportional representation, the fact that the two strongest parties RP and DYP were represented in the parliament at a ratio $(53,2 \%)$ higher than their vote power $(41 \%)$ due to the high country threshold giving results to the advantage of large parties, was caused by the attributes of the system leading to surplus representation to the advantage of large parties.

The two strongest parties had the lowest vote $(40,2 \%)$ in the 1999 elections among the 5 elections held during the period 1999-2015. Thereafter, the total votes of these parties gradually increased up to $75,8 \%$ in 2011 and then dropped once again in the June 7 elections to $65,7 \%$ and increased to $74,8 \%$ in the November 1 elections. Examining in terms 
of the chair ratios of the two strongest parties, the $48,1 \%$ chair ratio in 1999 reached a very high ratio of 98,3\% due to the dominance of AK Parti in the parliament in 2002. Thereafter, it decreased down to $70,9 \%$ in June 7 and increased to $81,9 \%$ in November 1. 2002 was the elections with the highest disproportionality. The disproportionality ratio was $22,4 \%$ in these elections where AK Parti was represented was a large majority in the parliament and only two parties were in the legislature. This was caused by only two parties entering the parliament and in particular, the high national threshold had an important part in the situation. The fact that DYP with 9,5\%, MHP with 8,4\%, Genç Parti with 7,3\% and the Kurdish political movement with $6,2 \%$ vote were left outside the parliament was enough to describe the situation.

The 2002 elections can be considered as a typical example of the extent of injustice caused by a high threshold in a proportional representation system. Although the decrease in the number of parties (35,3\%) increased in the 2007 elections, the fact that representatives of the Kurdish political movement participated in the elections as independent candidates lead to the degree of disproportionality to reduce to $8 \%$. The decrease in the number of parties dropped to $20,7 \%$ in the 2011 elections and to $13,9 \%$ in the last elections and the disproportionality likewise remained at the level 5-5,2\%. Disproportionality was lowest in the November 1 elections $(3,4 \%)$. The fact that the degree of disproportionality had a decreasing trend since 2011 is closely related to the fact that the Kurdish national movement put representatives in the parliament through independent candidates and eliminated the impact of the national threshold. The strategic alliance that electors established with HDP in the ballot box in order to have this party pass the threshold in the June 7 elections was significant in terms of indicating how the threshold, developed as an electoral tool project could be crumbled with the will of the electorate. The vote and deputy ratios and the amount of vote received per deputy of the parties entering the parliament may be examined in order to observe the extent of the problem caused by the threshold method of the proportional representation system implemented in the elections held in the 1983-2015 period, in terms of reflecting the electoral performance of parties in the parliament.

The first point that draws attention in Table 3 is that the practice of threshold, which was put into proportional representation by the September 12 regime in the name of establishing political stability, served to establish single-party majorities as manufactured majorities (the strongest party gaining a majority of the chairs in the parliament despite not receiv- 
An assessment of the election system in Turkey

Table 3. Vote Per Deputy Received by Parties During the 1983-2015 Period

\begin{tabular}{|c|c|c|c|c|c|c|c|c|c|}
\hline & 1983 & 1987 & 1991 & 1995 & 1999 & 2002 & 2007 & 2011 & 2015 \\
\hline ANAP & $\begin{array}{c}45.1 \\
(52.9) \\
37123\end{array}$ & $\begin{array}{c}36.3 \\
(64.9) \\
29809\end{array}$ & $\begin{array}{c}24.0 \\
(25.6) \\
44413\end{array}$ & $\begin{array}{c}19.7 \\
(24.0) \\
41873\end{array}$ & $\begin{array}{c}13.2 \\
(15.6) \\
47941\end{array}$ & $\begin{array}{l}5.1 \\
(0)\end{array}$ & & & \\
\hline $\mathrm{HP}$ & $\begin{array}{c}30.5 \\
(29.3) \\
45177\end{array}$ & & & & & & & & \\
\hline MDP & $\begin{array}{c}23.3 \\
(17.8) \\
56858\end{array}$ & & & & & & & & \\
\hline SHP & & $\begin{array}{c}24.7 \\
(22.0) \\
59909\end{array}$ & $\begin{array}{c}20.8 \\
(19.6) \\
57574\end{array}$ & & & & & & \\
\hline DYP/DP & & $\begin{array}{c}19.1 \\
(13.1) \\
77746\end{array}$ & $\begin{array}{c}27.0 \\
(39.6) \\
37082\end{array}$ & $\begin{array}{c}19.2 \\
(24.5) \\
39970\end{array}$ & $\begin{array}{c}12.0 \\
(15.5) \\
44063\end{array}$ & $\begin{array}{l}9.5 \\
(0)\end{array}$ & $\begin{array}{l}5.4 \\
(0)\end{array}$ & $\begin{array}{l}0.7 \\
(0)\end{array}$ & $0.1(0)$ \\
\hline $\mathrm{RP} / \mathrm{FP}$ & - & $\begin{array}{l}7.2 \\
(0)\end{array}$ & $\begin{array}{c}16.9 \\
(13.8) \\
66473\end{array}$ & $\begin{array}{c}21.4 \\
(28.7) \\
38053\end{array}$ & $\begin{array}{c}15.4 \\
(20.2) \\
43291\end{array}$ & & & & \\
\hline DSP & - & $\begin{array}{l}8.5 \\
(0)\end{array}$ & $\begin{array}{c}10.8 \\
(1.6) \\
374900\end{array}$ & $\begin{array}{c}14.6 \\
(13.8) \\
54184\end{array}$ & $\begin{array}{c}22.2 \\
(24.7) \\
50879\end{array}$ & $\begin{array}{l}1.2 \\
(0)\end{array}$ & $\begin{array}{l}0.0 \\
(0)\end{array}$ & $\begin{array}{l}0.3 \\
(0)\end{array}$ & $0.1(0)$ \\
\hline MHP & - & $\begin{array}{l}2.9 \\
(0)\end{array}$ & & $\begin{array}{l}8.2 \\
(0)\end{array}$ & $\begin{array}{c}18.0 \\
(23.5) \\
43461\end{array}$ & $\begin{array}{l}8.4 \\
(0)\end{array}$ & $\begin{array}{c}14.3 \\
(12.7) \\
70448\end{array}$ & $\begin{array}{l}13.0 \\
(9.6)\end{array}$ & $\begin{array}{c}16.2 \\
(14.5) \\
94000 \\
142353\end{array}$ \\
\hline $\mathrm{CHP}$ & - & - & - & $\begin{array}{c}10.7 \\
(8.9) \\
61450\end{array}$ & $\begin{array}{l}8.7 \\
(0)\end{array}$ & $\begin{array}{c}19.4 \\
(32.4) \\
34344\end{array}$ & $\begin{array}{c}20.9 \\
(20.4) \\
65337\end{array}$ & $\begin{array}{c}26.0 \\
(24.5) \\
82636\end{array}$ & $\begin{array}{c}24.9 \\
(24) \\
87258 \\
90386\end{array}$ \\
\hline HADEP & - & - & - & $\begin{array}{l}4.2 \\
(0)\end{array}$ & $\begin{array}{l}4.7 \\
(0)\end{array}$ & & & & \\
\hline AK Parti & - & - & - & - & - & $\begin{array}{c}34.3 \\
(66.0) \\
29774\end{array}$ & $\begin{array}{c}46.6 \\
(62.0) \\
47880\end{array}$ & $\begin{array}{c}49.8 \\
(59.3) \\
65440\end{array}$ & $\begin{array}{c}40.8 \\
(46.9) \\
73129 \\
74706\end{array}$ \\
\hline
\end{tabular}




\begin{tabular}{|l|c|c|c|c|c|c|c|c|c|}
\hline & $\mathbf{1 9 8 3}$ & $\mathbf{1 9 8 7}$ & $\mathbf{1 9 9 1}$ & $\mathbf{1 9 9 5}$ & $\mathbf{1 9 9 9}$ & $\mathbf{2 0 0 2}$ & $\mathbf{2 0 0 7}$ & $\mathbf{2 0 1 1}$ & $\mathbf{2 0 1 5}$ \\
\hline SAADET & - & - & - & - & - & $\begin{array}{c}2.5 \\
(0)\end{array}$ & $\begin{array}{c}2.3 \\
(0)\end{array}$ & $\begin{array}{c}1.2 \\
(0)\end{array}$ & $2.0(0)$ \\
\hline $\begin{array}{l}\text { DEHAP/ } \\
\text { Indp./ } \\
\text { HDP }\end{array}$ & - & - & - & - & - & $\begin{array}{c}6.2 \\
(0)\end{array}$ & $\begin{array}{c}5.2 \\
(4.0)\end{array}$ & $\begin{array}{c}6.6 \\
(6.5)\end{array}$ & $\begin{array}{c}13.1 \\
(14.5) \\
70595\end{array}$ \\
\hline $\begin{array}{l}\text { GENÇ } \\
\text { Parti }\end{array}$ & - & - & - & - & - & $\begin{array}{c}7.3 \\
(0)\end{array}$ & $\begin{array}{c}3.0 \\
(0)\end{array}$ & - & - \\
\hline
\end{tabular}

ing a majority vote) in the 1983, 1987, 2002 and 2007 elections. The fact that AK Parti gained 59,3\% of the chairs in the parliament with a vote of $49,8 \%$ in the 2011 elections is considered as coming very close to earned majority [6, p. 102].

Manufactured majorities are naturally related to the fact that the votes of other parties are not reflected to the parliament with justice. The data in the table indicates that the situation in the relation between the vote ratios and chair ratios of parties is to the advantage of large parties to the extent which does not require a statistical analysis. Threshold practices are the main reason that such a result emerges. The fact that ANAP, the largest party in in 1983 and 1987, despite receiving vote ratios of 45,1\% and $36,3 \%$ respectively, achieved $52,9 \%$ and $64,9 \%$ chair ratios cannot be explained with any other reason. Likewise, the fact that AK Parti, which received $34,3 \%, 46,6 \%$ and $49,8 \%$ respectively in 2002, 2007 and 2011 gained $66 \%, 62 \%$ and $59,3 \%$ of the representatives explains the extent to which the national threshold leads to overrepresentation of large parties. This trend can also be observed by examining the vote received by parties per deputy. According to our calculations, the amount of vote per deputy of the largest party of an election is lower compared to other parties. Although the constituencies and the electoral geographies of parties have impact it this, it is clear that the electoral system is the actual determinant. ANAP, becoming the largest party in 1983 could receive 37123 votes per deputy whereas MDP, the third party in the elections had to receive 56858 votes per deputy. The fact that one hand DYP, the largest party of the 1991 elections could receive 37082 votes per deputy and on the other hand DSP, which entered the parliament with a vote of $10,8 \%$ had to receive 374900 votes per deputy, is a typical example of the 
deformity based on the electoral system, between the vote and chair performance of parties. While AK Parti could receive 47880 votes per deputy in 2007, CHP had to receive 65337 votes per deputy. The situation did not change much in the June 7 elections. AK Parti could receive 73 129, MHP 94000 and CHP 87258 votes per deputy and independent candidates had to receive 75731 votes to enter the parliament. The number of votes that parties had to receive per deputy increased in November 1 . This increase is especially evident in MHP. The number of votes MHP had to receive per deputy was 142 353. It is once again reveals that proportional representation is not very just and representative in terms of justice.

Another aspect to be examined regarding Electoral Systems and Justice is the number of deputies and the amount of vote required per deputy in various constituencies of Turkey, examining this for the case of November 1 elections reveals the following (table 4 ):

Table 4

\begin{tabular}{|c|c|c|c|c|}
\hline Constituencies & $\begin{array}{l}\text { Registered } \\
\text { Electors }\end{array}$ & $\begin{array}{c}\text { Vote } \\
\text { Required } \\
\text { Per Deputy }\end{array}$ & $\begin{array}{c}\text { Number of } \\
\text { Deputies }\end{array}$ & $\begin{array}{l}\text { Ratio of Vote } \\
\text { Required Per Deputy } \\
\text { to the Number of } \\
\text { registered Electors (\%) }\end{array}$ \\
\hline Adana & 1484820 & 106058 & 14 & 7,1 \\
\hline Adiyaman & 381687 & 76337 & 5 & 19,9 \\
\hline Afyonkarahisar & 495461 & 99092 & 5 & 19,9 \\
\hline Ağr 1 & 289454 & 72363 & 4 & 24,9 \\
\hline Amasya & 239079 & 79693 & 3 & 33,3 \\
\hline Ankara1 & 2099001 & 116611 & 18 & 5,5 \\
\hline Ankara2 & 1646705 & 117621 & 14 & 7,1 \\
\hline Antalya & 1589439 & 113531 & 14 & 7,1 \\
\hline Artvin & 129418 & 64709 & 2 & 50 \\
\hline Aydin & 777563 & 111080 & 7 & 14,3 \\
\hline Balıkesir & 910091 & 113761 & 8 & 12,5 \\
\hline Bilecik & 149018 & 74509 & 2 & 50 \\
\hline Bingöl & 171258 & 57086 & 3 & 33,3 \\
\hline
\end{tabular}


Tanju Tosun, Gülgün Erdoğan Tosun, Yusufcan Gökmen

\begin{tabular}{|c|c|c|c|c|}
\hline Constituencies & $\begin{array}{l}\text { Registered } \\
\text { Electors }\end{array}$ & $\begin{array}{c}\text { Vote } \\
\text { Required } \\
\text { Per Deputy }\end{array}$ & $\begin{array}{c}\text { Number of } \\
\text { Deputies }\end{array}$ & $\begin{array}{l}\text { Ratio of Vote } \\
\text { Required Per Deputy } \\
\text { to the Number of } \\
\text { registered Electors (\%) }\end{array}$ \\
\hline Bitlis & 190205 & 63401 & 3 & 33,3 \\
\hline Bolu & 213085 & 71028 & 3 & 33,3 \\
\hline Burdur & 191274 & 63758 & 3 & 33,3 \\
\hline Bursa & 2046276 & 113682 & 18 & 5,5 \\
\hline Çanakkale & 388577 & 97144 & 4 & 24,9 \\
\hline Çankırı & 129979 & 32494 & 4 & 24,9 \\
\hline Çorum & 385753 & 96438 & 4 & 24,9 \\
\hline Denizli & 718251 & 102607 & 7 & 14,3 \\
\hline Diyarbakır & 959078 & 87188 & 11 & 9,0 \\
\hline Edirne & 304729 & 101576 & 3 & 33,3 \\
\hline Elazığ & 398411 & 99602 & 4 & 24,9 \\
\hline Erzincan & 152578 & 76289 & 2 & 50 \\
\hline Erzurum & 483561 & 80593 & 6 & 16,6 \\
\hline Eskişehir & 616751 & 102791 & 6 & 16,6 \\
\hline Gaziantep & 1139452 & 94954 & 12 & 8,3 \\
\hline Giresun & 320720 & 80180 & 4 & 24,9 \\
\hline Gümüşhane & 93165 & 46582 & 2 & 50 \\
\hline Hakkari & 157379 & 52459 & 3 & 33,3 \\
\hline Hatay & 992286 & 99228 & 10 & 9,9 \\
\hline Isparta & 304143 & 76035 & 4 & 24,9 \\
\hline Mersin & 1218738 & 110794 & 11 & 9,0 \\
\hline Istanbul1 & 3719755 & 119992 & 31 & 3,2 \\
\hline Istanbul 2 & 3060263 & 117702 & 26 & 3,8 \\
\hline Istanbul3 & 3538185 & 114135 & 31 & 3,2 \\
\hline
\end{tabular}


An assessment of the election system in Turkey

\begin{tabular}{|c|c|c|c|c|}
\hline Constituencies & $\begin{array}{l}\text { Registered } \\
\text { Electors }\end{array}$ & $\begin{array}{c}\text { Vote } \\
\text { Required } \\
\text { Per Deputy }\end{array}$ & $\begin{array}{c}\text { Number of } \\
\text { Deputies }\end{array}$ & $\begin{array}{l}\text { Ratio of Vote } \\
\text { Required Per Deputy } \\
\text { to the Number of } \\
\text { registered Electors (\%) }\end{array}$ \\
\hline İzmir1 & 1522924 & 117148 & 13 & 7,7 \\
\hline İzmir2 & 1583326 & 121794 & 13 & 7,7 \\
\hline Kars & 182836 & 60945 & 3 & 33,3 \\
\hline Kastamonu & 277244 & 92414 & 3 & 33,3 \\
\hline Kayseri & 908971 & 100996 & 9 & 11,1 \\
\hline Kirklareli & 265061 & 88353 & 3 & 33,3 \\
\hline Kırşehir & 160467 & 80233 & 2 & 50 \\
\hline Kocaeli & 1241282 & 112843 & 11 & 9,0 \\
\hline Konya & 1437639 & 102688 & 14 & 7,1 \\
\hline Kütahya & 419508 & 104877 & 4 & 24,9 \\
\hline Malatya & 534774 & 89129 & 6 & 16,6 \\
\hline Manisa & 1010966 & 112329 & 9 & 11,1 \\
\hline K. Maraş & 700597 & 87574 & 8 & 12,5 \\
\hline Mardin & 445455 & 74242 & 6 & 16,6 \\
\hline Muğla & 673642 & 112273 & 6 & 16,6 \\
\hline Muş & 220874 & 73624 & 3 & 33,3 \\
\hline Nevşehir & 204214 & 68071 & 3 & 33,3 \\
\hline Niğde & 229962 & 76654 & 3 & 33,3 \\
\hline Ordu & 229962 & 45992 & 5 & 19.9 \\
\hline Rize & 243212 & 81070 & 3 & 33,3 \\
\hline Sakarya & 668777 & 95539 & 7 & 14,2 \\
\hline Samsun & 924381 & 102709 & 9 & 11,1 \\
\hline Siirt & 168993 & 56331 & 3 & 33,3 \\
\hline Sinop & 154707 & 78853 & 2 & 50 \\
\hline
\end{tabular}


Tanju Tosun, Gülgün Erdoğan Tosun, Yusufcan Gökmen

\begin{tabular}{|c|c|c|c|c|}
\hline Constituencies & $\begin{array}{l}\text { Registered } \\
\text { Electors }\end{array}$ & $\begin{array}{c}\text { Vote } \\
\text { Required } \\
\text { Per Deputy }\end{array}$ & $\begin{array}{c}\text { Number of } \\
\text { Deputies }\end{array}$ & $\begin{array}{l}\text { Ratio of Vote } \\
\text { Required Per Deputy } \\
\text { to the Number of } \\
\text { registered Electors (\%) }\end{array}$ \\
\hline Sivas & 435685 & 87137 & 5 & 19,9 \\
\hline Tekirdağ & 673481 & 112246 & 6 & 16,6 \\
\hline Tokat & 411684 & 82336 & 5 & 19,9 \\
\hline Trabzon & 561114 & 93519 & 6 & 16,6 \\
\hline Tunceli & 62615 & 31307 & 2 & 50 \\
\hline Şanlıurfa & 977938 & 81494 & 12 & 8,3 \\
\hline Uşak & 257681 & 85893 & 3 & 33,3 \\
\hline Van & 600503 & 75062 & 8 & 12,5 \\
\hline Yozgat & 295666 & 73916 & 4 & 24,9 \\
\hline Zonguldak & 446210 & 89242 & 5 & 19,9 \\
\hline Aksaray & 254480 & 84826 & 3 & 33,3 \\
\hline Bayburt & 52698 & 26349 & 2 & 50 \\
\hline Karaman & 167870 & 83935 & 2 & 50 \\
\hline Kırıkkale & 193688 & 64562 & 3 & 33,3 \\
\hline Batman & 312571 & 78142 & 4 & 24,9 \\
\hline Şırnak & 243624 & 60906 & 4 & 24,9 \\
\hline Bartın & 143384 & 71692 & 2 & 50 \\
\hline Ardahan & 68865 & 34432 & 2 & 50 \\
\hline Iğdır & 115464 & 57732 & 2 & 50 \\
\hline Yalova & 168185 & 84092 & 2 & 50 \\
\hline Karabük & 168503 & 84251 & 2 & 50 \\
\hline Kilis & 78926 & 39463 & 2 & 50 \\
\hline Osmaniye & 339157 & 84789 & 4 & 24,9 \\
\hline Düzce & 255464 & 85154 & 3 & 33,3 \\
\hline
\end{tabular}


As can be observed in the table, there is a serious imbalance in the number of electors required per deputy in the constituencies of the provinces of Turkey. For example, in the vote required per deputy was 121794 in the constituency İzmir 2119992 in the constituency Istanbul 1 and 117621 in the constituency Ankara 2 whereas it was 26349 in Bayburt, 31307 in Tunceli and 32494 Çankırı.

The vote distributions and elector deployments of parties in the June 7 and November 1 elections have confirmed that the dominant party system has settled in Turkey and that Ak Parti is the hegemonic party in this system. The deputy distributions of parties would not change in the November 1 elections even if the threshold was reduced by $1 \%$. This is because even the vote ratio of the 5th party Saadet Partisi, which could not enter the parliament did not reach $1 \%(0,68 \%)$. Under these given conditions and given that the executive will dominate over the legislature with the Presidential system in the forthcoming period and the executive will not be chosen from the legislature, the most essential issue in terms of the electoral system will be to not consider the principle of «Stability in Government» as in the past, but to strictly establish justice in representation in the parliament.

The Single-Member or Narrow Constituency electoral systems are being expressed in particular by government circles for a while as an alternative electoral system and it is understood that this system will be debated intensely in the politics of the country in the coming days. It should be stated in advance that the Single-Member or Narrow Constituency Systems do not provide justice in representation. At this point we would like to discuss the major attributes and the advantages and disadvantages of both systems.

Evaluation of Single-Member and Narrow Constituency Electoral Systems for Turkey. Intensely debated in the public opinion of Turkey, the Single-Member Constituency electoral system is an implemented method of the majoritarian system whereas the Narrow Constituency system is a proportional representation method. In the single-member constituency majoritarian system each constituency elects one representative and the constituencies consist of small areas and narrow regions. A list of the candidates is provided to the electors in the constituencies and they are asked to vote for one. The candidate who receives the highest vote in these narrow constituencies gets elected, thus each constituency has a single representative. This method is implemented in three ways. The first is the First-Past-the-Post system which is based on the candidate receiving 
the highest vote among the candidates competing in a single round in a constituency gets elected in that constituency. This is known as First-Pastthe-Post. This system is implemented in the UK House of Commons Elections, Singapore presidential elections, Canada and India parliamentary elections and in Belize, certain Caribbean countries, Bangladesh, Burma, Malaysia and Nepal. Another implementation of the first-past-the-post single-member constituency system is the Alternative Vote system where unlike this simple majority, the electors are given the opportunity to sort the candidates according to their preferences. It is based not on vote majoritarianism but on o candidate receiving a majority of the votes and operates with one-round and gives the opportunity for sorting preferences. The Australian general elections are its most typical implementation. It is also implemented in Fiji and Papua New Guinea. In the Runoff Single-Member Constituency system if a single candidate fails to receive the majority of the votes in the first round then the candidates achieving a certain vote ratio (e. g. 25 percent) or a certain number of candidates with the highest votes in the first round compete in the second round and the candidate receiving the highest vote in this round gets elected. The French Presidential elections are held with this method*. It is also implemented in the Central African Republic, Mali, Togo, Gabon, Congo, Belarus, Kyrgyzstan and Uzbekistan.

\section{Advantages and Disadvantages of the Single-Member Constituency} System. Defenders of the single-member constituency state that this system has significant advantages. These advantages are the ease at which electors understand the system, ease in making preference, ability of electors to get to know the candidates well, ability of electors to establish stronger bonds with their representatives as they get to know them better, easier accountability of the representative, possibility of representing all regions of the country at micro level, the fact that this method usually allows the formation of single-party governments and is prone to stability in government. Also, this method intends to have electors prefer one of two parties which contributes to the formation of a two-party system in the country it is implemented.

In the single-member constituency system electors have the potential to get to know most of the candidates which may cause more conscious voting. Narrow constituencies result in a strong elector representation because each elector has a single representative. Narrow constituencies grant the electors a very evident connection point with the parliament and this emphasizes service to the electors of the constituency. Narrow constitu- 
encies emphasize accountability because the elected deputy shall be held responsible for their performance and shall be rewarded by re-election or be punished by not getting elected in the next elections. Narrow constituencies guarantee the representation of all geographical (narrow) constituencies of the country. In single-member constituency systems parties are forced to tend towards candidates preferred by the electors of the region (through preliminary election or public opinion surveys) rather than the candidates they prefer. And this ensures the elimination of the tyranny of party leaders and contributes to intra-party democracy. Single-member constituency systems usually lead to single-party governments (and therefore to stability in government) and a single opposition party. As seen in the cases of USA and UK, this system leads the electors to two parties.

Conversely, the most important disadvantages of the single-member constituency system include its failure to take injustice into consideration, represent strong parties in the constituencies more in the parliament while lowering the representation opportunities of small parties in the parliament. On the other hand, each single-member constituency shall be represented by a single deputy with a certain political opinion and a significant section of the electors in the constituency will not be able to express their opinions and expectations in the parliament. If there are multiple parties of similar strength in the constituency, a first-past-thepost election will result in deputy election with minority vote in the constituency. The election may become meaningless in constituencies where one party is far ahead. (In 1998 in the USA in the state parliamentary elections were not held in $40 \%$ of the constituencies because one party was very strong, and a second candidate was not nominated.) For ethnic and religious minorities to be represented in the parliament, narrow constituencies where they have majority must exist (or be created). Single-member constituency systems lead to emergence of regional parties and may thus damage the national political system (as seen in Canada and India). As the single-member constituency system strengthens local candidates with regional power (especially in small provinces) it may weaken party organizations. The single-member constituency system may make it more difficult for women to enter the parliament ${ }^{1}$. In this context, this electoral system has disadvantages such as exclusion of minority parties, exclusion of women, wasting many votes, usually requiring additional elections,

${ }^{1}$ Erhan Erkut. Dar Bölge Sistemi Üzerine. Erhanerkut.com. Date of acces Nov. 1, 2017. 
leading to Gerrymandering and difficulty in encouraging participation in the elections. Also, in societies with strong feudal relations, persons with influence over a region can be nominated as candidates by political parties and these candidates may use their influence to get elected. Therefore, whether this system will result in positive consequences in a region with clans, communities, land lords and masters, is an issue to be considered seriously. On the other hand, a candidate with power and influence over the people in a certain region can use certain methods called "vote buying" in the literature and which means providing benefits to electors in exchange for their votes ${ }^{2}$. The potential of this possible drawback of the single-member constituency system in particular, to cause ethical problems in politics and to seriously threaten democracy should not be ignored.

\section{Advantages and Disadvantages of the Narrow Constituency System.} The Narrow Constituency electoral method is a practice basically implemented in the proportional representation system and which is based on having low number of deputies compared to wider constituencies. In this context, this method is based on having more deputies compared to the single-member constituency system in general but less than the wide constituencies of the proportional representation system. In practice, in this method the constituencies are arranged to be represented by 5-7 deputies. Although the aim in this method seems to be to achieve stability as an advantage, it has numerous disadvantages. Stability in management is emphasized as the advantage of this method. As constituencies are narrowed compared to the wide constituency practice of proportional representation and as a more organic relation is established between the electors and the elected, it is claimed to be a method more inclined to allow electors to know their representatives better and for better accountability. Likewise, it is claimed that geographical, social and cultural representation shall be at higher levels because the constituencies are narrowed. As the number of deputies to be elected from the constituency shall be lower in this method compared to wide constituencies, it is stated that deputies shall express and seek solution for regional problems in the legislature with higher consciousness.

It should be noted that the advantages asserted for the narrow constituency electoral system do not have a strong basis. Like the single-member constituency method this system benefits the parties that are stronger throughout the country and may serve to have them send more represent-

${ }^{2}$ Levent Gönenç. Dar Bölge Seçim Sistemi Tartışmaları. tepav.org.tr. 
atives to the parliament. Compared to the wide constituency system it is very difficult for parties with a social strength limited to a certain constituency to be represented in the parliament. On the other hand, as a single representative is not elected from the constituencies as in the case of single-member constituency systems, it is difficult to achieve certain benefits of the single-member constituency system using this method. Parties that are strong especially in the constituencies shall always have an advantage in this system. As multiple representatives get elected from constituencies and as it is still difficult for electors to contact and convey their requests to the elected, neither justice in representation, nor accountability can be realized as the required levels in this method.

Evaluation on Single-Member Constituency and Narrow Constituency Electoral Systems for Turkey. A new government system was accepted for Turkey with the April 16 referendum. Referred to as the presidential government system, as the executive will not be formed from within the legislature in this system and shall be appointed by the president, it parliamentary majority serving stability in government to be established by single-member or narrow constituency is not necessary anymore. The single-member or the narrow constituency methods focused on government stability in parliamentary systems may not provide stability in Turkey but in contrast, lead to instability and political polarization. Providing benefit especially to large and strong parties, these systems may lead to strong parties entering and be represented in the parliament with even more strength. And this may form not a pluralist but a majoritarian structure in the parliament. Although this leads to an effective government if the party with majority in the parliament is the same as the party of the president, plurality, democratic representation and the ability of the opposition to call for account shall be eliminated to a great extent.

Although issues such as electors getting to know their representative better, to call for them to account for their legislative activities and geographical representation are emphasized if the single-member constituency method is implemented, the style of politics in Turkey and the weakness of democratic values in the political culture will prevent this system from being functional. On the other hand, as especially primary bonds (town, community and clan bonds) are effective in single-member constituency systems particularly in underdeveloped or developing countries, these bonds and relation systems which exist in our country may lead to damages rather than benefits. The fact that strong parties and references based on primary bonds are effective in nomination of candidates may lead to 
a deficit in democratic politics. On the other hand, it is clear that the single-constituency system may conflict with article 80 of the Constitution. This article states the following: «Members of the Grand National Assembly of Turkey do not represent their constituency or their electors but the whole Nation». However, as the single-constituency system is based on establishing a strong bond between the electors and the deputies and as each deputy enters the parliament as the sole representative of a specific constituency and electorate, implementing this method is problematic in terms of the constitution ${ }^{3}$.

Like the single-member constituency system, as the narrow constituency system shall also benefit the large parties in Turkey, it will not provide any opportunity for small parties to enter the parliament or have small parties be underrepresented and thus lead to injustice in representation. If objective criteria are not implemented in determining the constituencies in this system, injustice in representation can be even more severe and may lead to geographical injustice in representation to the advantage of large parties. Although in essence this method is an implementation of proportional representation, in practice it may lead to as many problems as the majority system.

Our Proposal for an Electoral System to Strengthen Justice in Representation in Turkey. For the electoral system in Turkey to establish justice in representation it must strictly continue with the proportional representation system, however the electoral injustice caused by the $10 \%$ threshold must be eliminated. Taking into consideration the fact that the threshold cannot be fully eliminated, we provide below a new electoral system with an example, which we consider would make the system more representative in order to make votes given to parties serve justice in representation.

The first and most important steps to be taken for changing the electoral system is to decrease the electoral threshold from $10 \%$ to $5 \%$. Additionally, as recommended by Özbudun, election of 100 members of the parliament through proportional representation method from the country constituency may help to establish a more pluralist parliament. Özbudun asserts that if the country threshold cannot be reduced, the method implemented in countries such as Germany, Sweden and Denmark could be used where parties with the highest vote in a certain number of constituencies or vote above a certain ratio could be exempt from

\footnotetext{
${ }^{3}$ Gönenç, Ibid.
} 
the threshold, which would eliminate injustice in representation and also not damage stability [6, p. 118, 119]. In our opinion, despite reduction of the national threshold to 5 percent, in order to ensure that parties that are not represented in the parliament, but which are the strongest in a certain constituency or constituencies can have deputies, calculating the deputy distribution of all parties in those constituencies using again the d'Hondt method but by exempting them from the threshold in those constituencies, can strengthen justice in representation. For example; for a hypothetical parliament with 450 members if 100 members are elected through non-threshold proportional representation d'Hont method and 350 deputies are elected through 5 percent national threshold proportional representation d'Hondt method, then the total number of deputies in the constituencies where parties for which non-threshold calculation shall be made are first, can be subtracted from the total number of deputies where threshold calculation is to be made (350) and the remaining number of deputies can be distributed to the parties in accordance with their vote ratios.

According to the amount of votes received by parties in general elections, based on a calculation where in a parliament with 450 members, 100 members are elected through non-threshold proportional representation d'Hondt method from the country constituency, 350 members are elected through $5 \%$ national threshold proportional representation d'Hondt method and with the same method in the provinces where the parties are the 1st but by being exempt from the threshold (E.g.: In a country with a total of 50 constituencies Party E is the 1st party in a constituency with 10 deputies and Party F is the 1st in another constituency with 5 deputies) the distribution of deputies to the parties shall be as follows (table 5$)^{4}$.

In a parliament with 450 members, with an electoral system where 100 members are elected from the country constituency with non-threshold proportional representation d'Hondt method, 350 members are elected with $5 \%$ national threshold proportional threshold d'Hondt method and using the same method in the constituencies where the parties are

${ }^{4}$ Vote distribution of parties in the constituency with 10 deputies and where the Party E is the 1st party: Valid Votes: 1000 000, votes of parties: A: 200 000, B: 150 000, C: 100 000, D: 80 000, E: 300 000, F: 70 000, G: 60 000, H: 40 000. Vote distribution of parties in the constituency with 5 deputies and where the Party F is the 1st party: Valid Votes: 600 000. A: 150 000, B: 50 000, C: 20 000, D: 80 000, E: 60 000, F: 200 000, G: 10 000, H: 30000 . 
Table 5

\begin{tabular}{|c|c|c|c|c|}
\hline $\begin{array}{c}\text { Parties } \\
\text { Valid } \\
\text { Votes: } \\
45400000\end{array}$ & $\begin{array}{c}\text { Distribution of } \\
100 \text { Deputies } \\
\text { according to } \\
\text { non-threshold } \\
\text { Proportional } \\
\text { Representation } \\
\text { d'Hont (n) }\end{array}$ & $\begin{array}{l}\text { Distribution of } \\
335 \text { Deputies } \\
\text { according to } \\
5 \% \text { national } \\
\text { threshold } \\
\text { Proportional } \\
\text { Representation } \\
\text { d'Hondt (n) }\end{array}$ & $\begin{array}{l}\text { Distribution of } \\
15 \text { deputies in } \\
\text { provinces where } \\
\text { parties that } \\
\text { fail to pass the } \\
\text { threshold (E, F) } \\
\text { are the } 1 \text { st party }\end{array}$ & $\begin{array}{l}\text { Total deputy } \\
\text { distribution } \\
\text { (n) }\end{array}$ \\
\hline $\begin{array}{l}\text { Party A } \\
20000000\end{array}$ & 45 & 162 & $3+2$ & 212 \\
\hline $\begin{array}{l}\text { Party B } \\
14000000\end{array}$ & 31 & 113 & 2 & 146 \\
\hline $\begin{array}{l}\text { Party C } \\
7500000\end{array}$ & 17 & 60 & 1 & 78 \\
\hline $\begin{array}{l}\text { Party D } \\
1900000\end{array}$ & 4 & - & 1 & 5 \\
\hline $\begin{array}{l}\text { Party E } \\
1000000\end{array}$ & 2 & - & 4 & 6 \\
\hline $\begin{array}{l}\text { Party F } \\
500000\end{array}$ & 1 & - & 2 & 3 \\
\hline $\begin{array}{l}\text { Party G } \\
400000\end{array}$ & - & - & - & - \\
\hline $\begin{array}{l}\text { Party H } \\
100000\end{array}$ & - & - & - & - \\
\hline
\end{tabular}

In a system with $10 \%$ threshold Party A gets 217 deputies, Party B gets 152 and Party C gets 81 deputies. All 4 parties get deputies only if the threshold is reduced to $3 \%$ in which case the distribution becomes as follows: A: 208, B:145, C:78, D: 19

the 1 st but by being exempt from the threshold (E.g.: In a country with a total of 50 constituencies Party E is the 1st party in a constituency with 10 deputies and Party $\mathrm{F}$ is the 1st in another constituency with 5 deputies) parties $\mathrm{E}$ and $\mathrm{F}$ become the 1st party in their constituencies despite being unable to pass the $5 \%$ country threshold, would give these two parties extra deputies and it becomes possible to reflect to the parliament the vote preferences in the constituencies where they are strong in addition to their 
share from the 100 deputies. If especially class, ethnic or individual vote preferences predominate in these constituencies, the system is more inclusive in terms of justice in representation and democratic legitimacy as is reflects preferences into the parliament.

What Turkey needs after the June 7 elections is the construction of a more inclusive democracy rather than the exclusionary democracy of the recent years. Starting by improving the electoral system based on justice in representation could be one of the most significant contributions in strengthening Justice and democracy.

Conclusion. Electoral systems have been one of the most controversial topics in the political life of Turkey since the past. The main reason for this is that since 1946, when multi-party political life initiated, the political elites have failed to generate an electoral system on which all the parties including the government and the opposition to compromise even at a minimum level. As government parties in particular prefer the system that provide them the most numerical advantage, this approach results in a democratic deficit in Turkey through the electoral system. The national-threshold d'Hondt system currently implemented Turkey was a project imposed on politics through an electoral law prepared by the coup leaders of September 12. The aim was to establish in Turkey an electoral system where 2-2,5 parties would be effective in the parliament and that would provide a stable government. Although this aim of the September 12 coup leaders was effective until the early 1990s due to the double threshold in the electoral system, the sociological dynamics of politics later became dominant and a relatively pluralist parliamentary structure was formed despite the electoral system during the 90s until the November 3, 2002 general elections. The fact that Ak Parti was very strongly represented in the parliament in the 2002 elections was a result of the fact that the electoral system was unjust in representation this continued until the early 2010s. Today, the social divisions in the society have recently lead to the formation of a pluralist structure in the parliament despite the national threshold of the electoral system which prevents justice. In a sense, the contracting effect of the electoral system in the 80s was overcome in the 2000s with the preferences of the electors. However, today, when transition is made to the Presidential system, it is noteworthy the political power may propose the single-member constituency system which is a majoritarian system or the narrow constituency system where proportional representation gives majoritarian results, as the new electoral system in the name of political stability. Our opinion is that both systems may not 
lead to political stability in Turkey and in contrast, could lead to more unjust results in parliamentary representation. On the other hand, the most essential attributes of the electoral system we proposed are that it allows for small parties to also get represented in the parliament and that it emphasizes justice in representation. Our opinion is that how the electoral system can be established based on justice in representation shall be the fundamental question to be answered regarding the electoral system in the forthcoming days in Turkey. The system we proposed fully responds to this question.

\section{References}

1. Sabri Sayarı, Hasret Dikici Bilgin. Karşılaştırmalı Siyaset Temel Konular ve Yaklaşımlar. Bilgi Üniversitesi Yayınları (Akademik) Press.

2. Electoral Systems: A Primer for Decision Makers, Journal of Democracy, no. 14 (4), 2003, pp. 115-127.

3. Özbudun, Ergun. Seçim Sistemleri ve Türkiye. Ankara Üniversitesi Hukuk Fakültesi Dergisi, Cilt 44, Sayı 1-4, 1995, pp. 521-539. http://dergiler.ankara.edu.tr/dergiler/38/298/2768.pdf.

4. M. Gallagher ve P. Mitchell, der. The Politics of Electoral Systems. New York, Oxford University Systems Press, 2008.

5. Taagepera R.Effective Magnitude and Effective Threshold, Electoral Studies, 1998, no. 17(4), pp. 393-404.

6. Özbudun, Ergun. Türkiye'de Parti ve Seçim Sistemi. İstanbul, İstanbul Bilgi Üniversitesi Yayınları Press, 2011.

Author's information:

Tanju Tosun - Dr., Prof. Ege University

Gülgün Erdoğan Tosun - Dr., Prof. Ege University

Yusufcan Gökmen - Research Assistant, Ege University

Ege Üniversitesi, Rektörlüğ̈̈ Gençlik Caddesi, 35040, Bornova-Izmir, Turkey

${ }^{\star}$ A significant part of this study was prepared based on and quoted from the following work of Tanju Tosun: Tanju Tosun; Türkiye’de Seçim Sistemleri ve Seçimlere Etkisi, Liberal Perspektif Rapor, S: 1, Ankara, 2015. 